\title{
Toward a Feminist Reading of Herman Melville's Stories About the Material Conditions of Writing
}

\author{
$\underline{\text { Rodrigo Andrés }}$
}

Feminist criticism contributes a stimulating, if still compact, scholarshipin the field of Melville studies. The past three decades of feministstudy have not only revisited questions of Melville and misogyny,but also renewed interest in his short fiction, poetry, andPierre;opened upmultiple significances of gendered figures in his texts; reconsidered his careerthrough new historical models of authorship; and more. This year's MLA panelprovided the occasion to extend the inquiry in a range of approaches thataddress a range of texts

Heather Levy shows the importance of continued feminist critique andcareful reading to distinguish where Melville's writing may escape social hi-erarchies and where it remains embedded in his era's structures of inequality.Her study ofRedburntakes Melville at his word in pointing up a commercialmotive behind the novel's conformations to an inequitable social system andresultant shortfalls of human solidarity.Virginia Engholm extends the feminist project of literary recovery andrecuperation of the sentimental mode. Her comparison ofPierreandVioletaims to enlarge understanding of antebellum genre and family formation, aswell as to deepen appreciation of Melville's novel along with that of the fictionof his fellow New Yorker, Maria McIntosh.Rodrigo Andr' es frames a materialist feminist reading of Melville's shortfiction in biographical analysis. With a sympathetic understanding of unevenantebellum gender configurations, he tallies some of the costs of male privilege, material and status costs for women, as well as psychological costs for bothwomen and men, and traces these in the literary and psychological structuringof Melville's stories.Ellen Weinauer provided a response that, together with the panelists'papers, illustrated some of the many interesting, vital things that a feministmight do with Melville.

Elizabeth Hardwick optimistically suggests that "throughout Melville'swriting there is a liberality of mind, a freedom from tribal supersti-tion, a rejection of superiority of race or nation" (xvii). Hardwickemphasizes Wellingborough's indignant assessment of the failure of Americansto carry out the principles articulated in the Declaration of Independence.Redburndoes express egalitarian impulses about race and class, but they areonly momentary asides rather than the heart of Melville'sbildungsroman.AlthoughRedburnwas written one year after Elizabeth Cady Stanton andLucretia Mott first proposed votes for women at the Seneca Falls Woman'sRights Conference, it does not contain egalitarian impulses toward women ofany race or classRedburnoffers the feminist reader contrived tropes of womanhood,including the dutiful and sentimental mother who knits mittens and mendstrousers, the devoted but ineffectual sisters, an emaciated mother with her child in a pawn shop, and the generous wife Mrs. Jones withher heaping plates of maternal pudding.

Once Wellingborough sets out tosea, the circle of standard tropes is only slightly widened to encompassan eccentric old black fortune teller De Squak, "hoydenish nymphs," thesentimental daughter of the dock master, hopelessly domesticated wives whounwittingly 
participate in the roguish bigamy of their husband Max, HandsomeMary who tearfully accepts beatings from her laggardly husband, avariciousfemale prostitutes, the beautiful daughters of an English farmer with whomWellingborough becomes smitten, and upper class ladies who scornfullyoffer pennies to the most woeful Irish emigrants. Hardwick characterizesWellingborough's encounter with the starving mother and her beleagueredchildren who have crept off to die in an old factory warehouse cellar inLauncelott's-Hey as "a scene of tragic extremity, last rites for a street burial,a moment of perfect human sympathy" (xvii). Wellingborough does try tointercede on their behalf but cannot convince authorities to assist them. There are no last rites for the starving mother and her neglected children.Lime merely covers stench.

It is an emblem of ruthless practicality thateven more painfully underscores the failure of Wellingborough's attempts atcompassion. The feminist reader cannot help noticing that there is a lexicon of humanworth inRedburn.Jackson, the detested and lazy sailor falls from the rigging tohis death at the end of the voyage, a drunken sailor spontaneously combustsin his fetid berth (qtd. in Bernard 349), women on both sides of the Atlanticare beaten but stay in their marriages, and the bodies of the hapless motherand her starving children are first destroyed by neglect and then tidied overby a public willing to offer only lime. Compassion is a reluctant impulse forWellingborough. He is willing to hide his sexual and emotional desires forHarry Bolton and Carlo, the Italian singer. His ability to turn his poignantencounters with the poor, Blacks, Jews, Irish immigrants, and homosexualsinto convenient and lyrical emblems ensures his survival and the commercialsuccess ofRedburn.Love Will Keep Us Together: Sentimentalism andthe Problem of Incest in Melville'sPierreand Maria McIntosh'sVioletVirginia B. EngholmUniversity of Kentucky Cindy Weinstein's important recent bookFamily, Kinship, and Sym-pathy in NineteenthCentury American Literatureaddresses one of themost debated issues in the study of Herman Melville'sPierre, that of or not the novel can be considered sentimental. She points out thatmany critics see the novel's inability to "generate contractual relations," whatshe argues convincingly is a central concern of the genre, as evidence that thenovel is more a derisive comment on or subversive mockery of the conventionsof sentimental fiction than a genuine engagement with them (159).

Althoughshe asserts that this failure does separatePierrefrom other sentimental novels,she argues thatPierreretains some element of the sentimental in that Melville'snovel is in fact a precursor to it, a sentimental novel that never quite getsgoing.My intervention in this debate comes through reclamation ofPierreasa sentimental novel that, contrary to Weinstein's argument, works very muchwithin the genre of sentimentalism.

Whereas Weinstein viewsPierre'sinabilityto regenerate familial bonds based on affection as a failure and consequentlylocatesPierreas related to, but not part of, the genre itself, I contend that thisfailure is in fact symptomatic of the larger project of sentimentalism.At stake, particularly for feminist critics of both Melville and senti-mentalism, is the way in which this inability to reestablish familial bondsoutside the boundaries of consanguinity is viewed as evidence of Melville'sunwillingness or inability to write a sentimental novel, or more to the point,the way in which he is viewed as able to escape the "ideological and characterological problems of sentimental fictions" (159). PlacingPierreside byside with Maria McIntosh's widely read but critically neglected novelViolet, which also explores the limitations of sentimental novels' reimaginings of thefamily, helps to illustrate that even 
while Melville pushed against the limits ofthe sentimental novel's drive to create a new vision of the family, he hardlydid so alone. McIntosh'sVioletalso puts pressure on the dictate of these novelsthat affinity and sympathy would solve the problems of consanguinity. Its plot,which centers on the traditional narrative wherein the young, orphaned girl isadopted by successive families, brings in the problem of incest overtly (wheremost sentimental novels only deal with it implicitly) by having the final familythat adopts her as "their own daughter" actuallybeher biological family. Theheroine must literally escape the threat of incest, as her adoptive father wantsher to marry her biological brother.I argue thatPierreandViolet, when read together, show the extent towhich the notion of the reconstructed family carried within its very structurethe problem of incest. My argument makes clear that Melville's inability toreimagine the family as bound by affection and choice rather than consanguin-ity does not deny him the status of a sentimental writer and indeed places himsquarely within the genre's bounds.

Herman Melville's "Bartleby, the Scrivener" (1853) and "The Tartarusof Maids" (1855) both may be read as explorations of the gendereddimension of the job of the scrivener, that is, the copyist. In my read-ing, I suggest that these texts are informed by Herman Melville's considerationsof - and anxieties about — his gender privilege(s) within his household.During the 1840s and early 50s, while Melville was writing his novelsand short stories, his sisters and wife did all the revising and preparationfor printing. Lizzie, Helen and, especially, Augusta were responsible for theimmense task, the chore, of copying. So very busy was Augusta that Helenrealized that the bonds of sisterly love could, or had, become chains of quasi-enslavement, as she phrases it in a letter to Augusta: "I can sympathise [sic]in your state of entire employment" (qtd. in Parker 2.221). Whether Augustaever shared her brother's creative gift, talent, yearnings and literary aspiration,we will never know. Yet Augusta's letter to her friend Mary Blatchford may bepertinent here: "I really believe that I could at this moment indite a sonnet"(17 October 1850; qtd. in Parker 1.786). If she did ever have the time to write,her work was never printed.Was Herman Melville himself unaware of that potential in Augusta andperhaps his other sisters? Was he not conscious that, if it existed, it was beingsacrificed in their becoming mechanical copyists?Contemplating Herman Melville's necessary awareness of female sac-rifice invites an understanding of the story "Bartleby" according to whichHerman Melville may not identify only with the scrivener but also - uncomfortably - with the lawyer. Events for the year 1853 suggest parallelsbetween his sister's work and his works: "Melville apparently wrote 'Bartleby, the Scrivener' between mid-August and . . . mid-September. Augusta recordedno letters written between 6 and 24 August, a possible indication that shewas copying furiously" and possibly an indication that the story reflects onher copying (Parker 2.176). I therefore read "Bartleby" in the light of anotherMelville text, "The Tartarus of Maids" (1855), which also refers to the materialconditions of writing. In his visit to remote paper mills, the narrator of thestory realizes how women are the victims of the social division of labor, a partitioning which condemns them to produce paper-as women - whileit prevents them-as women - from having agency and visibility in writing.Melville's texts show how (male) publication may often come at the expenseAJOURNAL OFMELVILLESTUDIES121 EXTRACTSof the non-writing of women, whose yearning to say will go silenced anddisappear in the materiality of texts written by men.My reading of the stories contests David Leverenz's thesis that theAmerican Renaissance male writers suffered severe 
psychological hardshipsbecause they saw themselves as deviating from the gender expectations aboutthe type of activity appropriate to male Brahmins. Melville may not have seenhis masculinity with anxiety because of any deviance from gender expectationsin the America of the 1840s and 50s, but rather, on the contrary, with theanxiety of knowing gender as the granter of undeniable privileges for malewritersofhistimes.

I as feminist criticism allows us to talk about the politics of mas-culinity, or masculine identity formation, or sexuality, we've got an em-barrassment of riches in Melville. But insofar as feminist criticism devotesitself to representations of women, or representations of "women's" worlds andwork, we appear to have little to go on. Shortly before Melville's death, JulianHawthorne insisted that his father's one-time friend "wrote books that werecertainly not meant for women," calling them, first, "Man-Books" and then,in a diminishing amendment, "books of adventure-boys' books" (Leyda,Log2.810). In this remark, Hawthorne appears to some extent to be taking Melvilleat his own word, as in his well-known letter to Sophia Hawthorne, who hadread and praisedMoby-Dick: "It really amazed me that you should find anysatisfaction in that book," Melville writes; "It is true that somemenhave saidthey were pleased with it, but you are the onlywoman - for as a general thing,women have small taste for the sea. . . . But, My Dear Lady, I shall not againsend you a bowl of salt water. The next chalice I shall commend, will be a ruralbowl of milk" (Correspondence218-19). The "rural bowl of milk" refers, ofcourse, toPierre-a book that many have seen as demonstrating, spectacularly,Melville'sinability to write coherently, or with conviction, about the family,about domestic structures, about conventional marriage, or successfully toadopt and adapt the (feminized) sentimental form.Regardless of whether he writes "Man" or "boy-books," however,Melville still gives feminists something to do.If we have been slow to recognize, and then to reckon with, this - asour panel's winking title suggests - there is reason to hope that the criticallandscape is changing. and Women, the first collection of essays dedicated to the subject.Including essays treating Melville's lived relationships with women and hisreading of women writers, his explicit renderings of female characters and hisoften more implicit and "slant" exploration of gender roles and domesticity,the collection breaks a path through largely uncharted and promising terrain.It is this path that our session attempts to follow, marking out three various butrelated approaches to reading Melville through a feminist lens.

Taken together,these approaches open up what we might think of as a new, more narrowavenue of exploration: Melville and the family.This thematic link appears as a common denominator of all three papers,family and, in particular, sisters: the sentimental sisters from whom Welling-borough Redburn flees, the sister-mother and sister-wife ofPierre, the copyingsisters in Melville's own life. Directly (Engholm and Andr' es) and indirectly(Levy), our panelists have provided ample evidence that, whether focusingon male or on female characters, Melville is almost always talking aboutfamilies - biological and contractual, sympathetic and antipathetic. We couldsupplement their analyses by thinking about how family is read and reframedthrough, to cite just a few examples, Tommo and Toby, Redburn and HarryBolton, Ishmael and Queequeg, the "bachelors" and "virgins" of "Paradise" and"Tartarus," the waiting wife in the unfinished Agatha narrative. In short, ourpanelists make it apparent that, by reading Melville's work through the lens ofthe nineteenth-century family, whether real or imagined, we find the rich pieceof 
common ground between Melville and "the feminist" to which our panel'stitle hopefully alludes. 